\title{
Duchowość obrońcy życia człowieka i rodziny. Sylwetka duchowa i fenomen działalności dr. inż. Antoniego Zięby (1948-2018)
}

Wprowadzenie

W osobie dr. inż. Antoniego Zięby (1948-2018) w zadziwiający sposób umysł techniczny łączył się z autentycznym zaangażowaniem apostolskim, sprawnością wytrawnego mówcy, otwartością na pozytywny przekaz estetyczny i werbalny, a nade wszystko z wrażliwością na wartości humanistyczne, godność osobową człowieka i integralność rodziny. W swojej blisko czterdziestoletniej wielopłaszczyznowej działalności społecznej był on jednocześnie pracownikiem naukowym, nauczycielem akademickim, profesjonalnym wydawcą prasy katolickiej, dziennikarzem rozumiejącym twarde wymogi komunikacji medialnej, inicjatorem i koordynatorem stowarzyszeń 
i fundacji, strategiem planującym liczne działania na rzecz pełnej ochrony życia ludzkiego od poczęcia, dobroczyńcą wspierającym ubogie rodziny i samotne matki, pedagogiem wychowującym młodzież do czystości narzeczeńskiej i wierności małżeńskiej, człowiekiem heroicznie posłusznym Kościołowi i wreszcie osobą konsekwentnie wypełniającą chrześcijańskie powołanie do świętości jako mąż, ojciec, katolicki działacz i obrońca dzieci nienarodzonych. Spośród wielu możliwych charakterystyk postaci Antoniego Zięby na pierwszy plan wysuwa się jednak obraz nauczyciela i męża wytrwałej modlitwy, która kształtując jego głębokie życie duchowe, stanowiła źródło wielorakiej aktywności społecznej ukierunkowanej na realizację duchowego ojcostwa wobec zagrożonego dziecka rozwijającego się w łonie matki. Przedmiotem poniższego studium jest dokonanie wstępnej analizy sylwetki duchowej i fenomenu działalności pro-life tego krakowskiego obrońcy życia. Praca ta ma charakter propedeutyczny i jest zapowiedzią szerszego studium biograficzno-monograficznego.

\section{Fenomen działalności pro-life}

Jedną z najistotniejszych inicjatyw pastoralnych Antoniego Zięby jest powołana w 1980 roku Krucjata Modlitwy w Obronie Poczętych Dzieci skupiająca ponad 100 tysięcy uczestników, z której powstały kolejne dzieła, jak Fundacja „Pro Humana Vita” w Krakowie z wielospecjalistyczną poradnią medyczną oraz Światowa Krucjata Modlitwy w Intencji Obrony Życia Człowieka - World Prayer of Life zawiązana w 2007 roku podczas II Modlitewnego Kongresu dla Życia w Sanktuarium Bożego Miłosierdzia w Krakowie-Łagiewnikach ${ }^{1}$. Od początku istnienia Polskiej Federacji Ruchów Obrony

1 Por. E. Staniek, Charyzmatyk, „Źródło. Tygodnik Rodzin Katolickich” (20 maja 2018) nr 20 (1377), s. 7; D. Hybel, Wystarczy, że będziesz myślący, „Głos dla Życia” (majczerwiec 2018) nr 3 (152), s. 8; M. Cichoń, Odszedł wielki obrońca życia, „Niedziela” (13 maja 2018) nr 19, s. 17; J. Kawecki, S. Pyrak, Śp. drinż. Antoni Zięba (1948-2018), „Inżynieria i Budownictwo" nr 7-8 (2018), s. 439; A. Kisiel, Krucjata Modlitwy w Obronie Poczętych Dzieci, „Służba Życiu. Zeszyty Problemowe” 2 (2008), s. 18; J. Sosnowska, Inżynier o gorejącym sercu misjonarza, „WPIS” (25 kwietnia-23 maja 2018) nr 4 (90), s. 70-71; A. Zięba, Po 12 latach modlitwy stat się cud, „Miłujcie się" 3 (2018), s. 46; R. Michalik, Ocalał życie bezbronnych, „Źródło. Tygodnik Rodzin Katolickich” (20 maja 2018) 20 (1377), s. 30; M. Łącka, B. Gancarz, Fenomen Zięby, „Gość Niedzielny” (20 maja 2018) nr 20, s. 6; F. Ślusarczyk, Z wyobraź- 
Życia utworzonej w 1992 roku przez blisko dwadzieścia pięć lat Antoni Zięba pełnił funkcję wiceprezesa związku, odpowiadając za koordynację działań pro-life o zasięgu ogólnopolskim licznie zrzeszonych w federacji ruchów, stowarzyszeń, centrów pomocy rodzinie i duszpasterstw, zwłaszcza działań podejmowanych na rzecz wzmocnienia prawnej ochrony życia ludzkiego $\mathrm{w}$ okresie prenatalnym i normatywno-personalistycznego wychowania prorodzinnego młodzieży szkolnej². W 1999 roku założył dynamicznie się rozwijające Polskie Stowarzyszenie Obrońców Życia Człowieka w Krakowie, w którego ramach prowadził szeroką działalność wydawniczą, edukacyjno-wychowawczą i dobroczynno-charytatywną obejmującą pomocą materialną ubogie rodziny wielodzietne, matki w ciąży w trudnej sytuacji życiowej i matki samotnie wychowujące dzieci ${ }^{3}$. Dla formowania postaw pedagogów, wychowawców, katechetów i nauczycieli zgodnie z moralnością chrześcijańską i tradycjami narodowo-patriotycznymi powołał Polskie Stowarzyszenie Nauczycieli i Wychowawców ${ }^{4}$. Do jego głównych zadań należała promocja abstynenckiej edukacji seksualnej typu A i monitorowanie rozporządzeń ministerialnych, podstaw programowych, publikacji popularno-naukowych i podręczników szkolnych związanych z przedmiotem wychowanie do życia w rodzinie ${ }^{5}$. Nieodłącznym aspektem społecznego zaangażowania Antoniego Zięby był apostolat mediów katolickich, szczególnie prasy drukowanej. Wraz z zespołem współpracowników utworzył liczne tytuły prasy katolickiej adresowane do zróżnicowanej grupy odbiorców: dla studentów miesięcznik „Tryby”, dla młodzieży dwutygodnik „Droga” (ukazująca się także jako „Droga do Bierzmowania”), dla dzieci szkolnych miesięcznik „Dominik” (przekształcony później w periodyk „Dominik Idzie

nia miłosierdzia, „Źródło. Tygodnik Rodzin Katolickich” (20 maja 2018) nr 20 (1377), s. 14; J. Kawecki, Inżynier Antoni Zięba, obrońca życia człowieka, nasz przyjaciel i wspótpracownik, „Źródło. Tygodnik Rodzin Katolickich” nr 20 (1377), 20 maja 2018, s. 17.

2 Por. D. Hybel, Jubileusz 25 lat w stużbie życia i rodziny Polskiej Federacji Ruchów Obrony Życia, „Głos dla Życia” (maj-czerwiec 2018) nr 3 (152), s. 14-16.

3 Por. A. Zięba, Bronimy życia w Polsce i świecie, „Głos dla Życia” (czerwiec 2018) nr 3 (152), s. 18; Sprawozdanie merytoryczne z działalności Polskiego Stowarzyszenia Obrońców Życia Człowieka w Krakowie za rok 2017.

4 Por. Statut Polskiego Stowarzyszenia Nauczycieli i Wychowawców w Krakowie, Sprawozdanie z działalności Polskiego Stowarzyszenie Nauczycieli i Wychowawców za rok 2016.

Por. T. Król, J. Tęcza-Ćwierz, Kim był śp. Antoni Zięba?, „Wychowawca” (czerwiec 2018) nr 6 (302), s. 5. 
do Pierwszej Komunii Świętej”), dla dzieci przedszkolnych „Ola i Jaś”, jak również czasopisma przeznaczone dla rodzin: tygodnik „Źródło” i dwa miesięczniki „Nasza Arka” oraz „Cuda i Łaski Boże”. Do grupy tytułów ściśle prasowych dołączyły także dwa specjalistyczne pisma popularnonaukowe: „Służba Życiu. Zeszyty Problemowe” wydawane przez Polskie Stowarzyszenie Obrońców Życia Człowieka i „Wychowawca” redagowany przez Polskie Stowarzyszenie Nauczycieli i Wychowawców. Antoni Zięba był członkiem Zespołu Wspierania Radia Maryja w Służbie Bogu, Kościołowi, Ojczyźnie i Narodowi Polskiemu ${ }^{7}$. Na falach tej rozgłośni prowadził audycję „Zaczerpnij ze Źródła”, z kolei w TV Trwam program „Przegląd Tygodnika Rodzin Katolickich "Źródło»"8. Przez szereg lat pełnił funkcję wiceprezesa Katolickiego Stowarzyszenia Dziennikarzy9 ${ }^{9}$ Zainicjował również powstanie Podyplomowego Studium Dziennikarstwa przy krakowskim oddziale stowarzyszenia $^{10}$. Należał ponadto do Rycerstwa Niepokalanej, Rycerstwa Orderu Jasnogórskiej Bogurodzicy, Zakonu Rycerzy Kolumba, Zakonu Rycerskiego Świętego Grobu Bożego w Jerozolimie ${ }^{11}$. Otrzymał liczne odznaczenia za zasługi dla ochrony życia ludzkiego, oświaty i wychowania, a także rozwoju apostolatu prasy katolickiej: medal Senatu RP, Medal Komisji Edukacji Narodowej, nagrodę Fundacji Jana Pawła II, nagrodę im. św. Maksymiliana Marii Kolbego Katolickiego Stowarzyszenia Dziennikarzy, nagrodę

6 Por. M. Guziak-Nowak, Inżynierze, dziękuję, „Przewodnik Katolicki” (13 maja 2018) nr 19, s. 33; A. Puścikowska, Zmart działacz pro-life, „Gość Niedzielny” (13 maja 2018) nr 19, s. 13; J. Kawecki, Inżynier Antoni Zięba, obrońca życia, nasz przyjaciel i wspótpracownik, dz. cyt., s. 17-18; J. Sosnowska, Inżynier o gorejącym sercu misjonarza, dz. cyt., s. 71.

7 Por. B. Falkowska, Testament obrońcy życia, „Nasz Dziennik” (5-6 maja 2018) nr 102 (6156), s. 1; J. Kawecki, S. Pyrak, Śp. dr inż. Antoni Zięba (1948-2018), dz. cyt., s. 440.

8 Por. M. Bochenek, Pozostanie wzorem, „Nasz Dziennik” (9 maja 2018) nr 105 (6159), s. 15; J. Kawecki, S. Pyrak, Śp. dr inż. Antoni Zięba (1948-2018), dz. cyt., s. 439; J. Kawecki, Inżynier Antoni Zięba, obrońca życia, nasz przyjaciel i wspótpracownik, dz. cyt., s. 18; S. Mazurczak, Śp. Antoni Zięba - Stuga Życia 1948-2018, „W Naszej Rodzinie” (czerwiec 2018) nr 6 (101), s. 19.

9 Por. J. Sosnowska, Inżynier o gorejącym sercu misjonarza, dz. cyt., s. 71.

10 Por. T. Król, J. Tęcza-Ćwierz, Kim był śp. Antoni Zięba?, dz. cyt., s. 6.

11 Por. S. M. Piętka OFMConv., „Kapłanie Boży” - w stuchawce telefonu, „Źródło. Tygodnik Rodzin Katolickich" (20 maja 2018) nr 20 (1377), s. 6; J. Kawecki, Inżynier Antoni Zięba, obrońca życia człowieka, nasz przyjaciel i wspólpracownik, dz. cyt., s. 20; J. A. Nalaskowski OSPPE, Śp. Antoni, nasz rycerzu, dziękujemy Ci za to, że byłeś wśród nas, „Źródło. Tygodnik Rodzin Katolickich” (20 maja 2018) nr 20 (1377), s. 26; J. Dąbrowski, Panie, nie pytam, dlaczego go zabrałeś, lecz dziękuję za to, że nam go dałeś, „Źródło. Tygodnik Rodzin Katolickich” (27 maja 2018) nr 21 (1378), s. 8. 
„Bez światło-cienia” krakowskiego oddziału tego stowarzyszenia, nagrodę miesięcznika „Powściągliwość i Praca”, nagrodę im. Włodzimierza Pietrzaka i nagrodę „Anioła Życia” Zakonu Rycerzy Jana Pawła II ${ }^{12}$. Najważniejszym wyróżnieniem był jednak medal „Pro Ecclesia et Pontifice” przyznany mu przez papieża Franciszka niespełna kilka miesięcy przed śmiercią, który stanowił uwieńczenie jego działalności społecznej dla Kościoła i papieża ${ }^{13}$.

Posługę w dziele obrony człowieka od poczęcia do naturalnej śmierci inż. Zięba uważał za swoje najważniejsze życiowe powołanie ${ }^{14}$. W jednym z wywiadów wyznał: „Kocham życie i uczestniczę we wspaniałym dziele jego ochrony"15. Siłę perswazji zawdzięczał merytorycznym argumentom mającym interdyscyplinarne zakorzenienie w różnych specjalnościach naukowych: historii, medycynie, psychologii, pedagogice, filozofii, prawie i wreszcie teologii ${ }^{16}$. Fascynował się rozwojem prenatalnym człowieka - zachwyt wzbudzała w nim dłoń dziecka w dwunastym tygodniu ciąży ${ }^{17}$. Był przekonany, iż życie ludzkie i godność osobowa człowieka, przysługująca mu od poczęcia, nie są kwestią światopoglądu czy wyznawanej religii, ale faktem naukowym. Ścisła współpraca ze specjalistami różnych gałęzi medycyny, pedagogami, socjologiami i psychologami pozwalała mu publikować profesjonalne artykuły naukowe i popularno-naukowe oraz opracowania książkowe podejmujące szeroko pojętą tematykę pro-life i wychowania do

12 Por. S. Mazurczak, Śp. Antoni Zięba - Stuga Życia 1948-2018, dz. cyt., s. 19; M. Cichoń, Odszedł wielki obrońca życia, dz. cyt., s. 16; J. Sosnowska, Inżynier o gorejacym sercu misjonarza, dz. cyt., s. 71-72; J. Tęcza-Ćwierz, Uhonorowany za działalność pro-life, „Źródło. Tygodnik Rodzin Katolickich" (20 maja 2018) nr 20 (1377), s. 9-11; A. Puścikowska, Zmarł działacz pro life, dz. cyt., s. 13.

13 Por. J. Sosnowska, Inżynier o gorejacym sercu misjonarza, dz. cyt., s. 71-72.

14 Por. D. Hybel, Odszedł charyzmatyczny obrońca życia, „Głos dla Życia” (maj-czerwiec 2018) nr 3 (152), s. 4; J. Sosnowska, Inżynier o gorejącym sercu misjonarza, dz. cyt., s. 71; P. Wosicki, W temacie obrony życia - bezkompromisowy, „Źródło. Tygodnik Rodzin Katolickich" (20 maja 2018) nr 20 (1377), s. 24.

15 Por. M. Cichoń, Jak Inżynier został obrońcą życia, „Niedziela” (8 kwietnia 2018) nr 14, s. 27.

16 Por. T. Król, J. Tęcza-Ćwierz, Kim był śp. Antoni Zięba?, dz. cyt., s. 6; P. Wosicki, $W$ temacie obrony życia - bezkompromisowy, dz. cyt., 24; J. A. Nalaskowski OSPPE, Śp. Antoni, nasz rycerzu, dziękujemy Ci za to, że byłeś wśród nas, dz. cyt., s. 26; R. Michalik, Ocalał $\dot{z}$ ycie bezbronnych, dz. cyt., s. 30 .

17 Por. K. Gałuszka (b), Nauczył mnie zachwytu nad życiem, „Nasza Arka” (2018) nr 6 (210), s. 21. 
życia w rodzinie ${ }^{18}$. Równocześnie inż. Zięba potrafił precyzyjnie wyrażać swoje poglądy religijne i etyczne, umiejętnie oddzielając je od argumentacji ściśle naukowej. Odznaczał się bardzo dobrą znajomością teologii katolickiej i nauczania Kościoła, zwłaszcza z okresu pontyfikatu Jana Pawła II ${ }^{19}$. Pomimo wykształcenia technicznego w 2016 roku uzyskał członkostwo w Polskim Towarzystwie Teologicznym ${ }^{20}$. Cieszył się życzliwością i zaufaniem polskiego papieża, który w ciągu długiego pontyfikatu przyjmował go sześćdziesiąt trzy razy podczas prywatnych audiencji ${ }^{21}$. Jak potwierdza kard. Stanisław Dziwisz, inż. Zięba swoje inicjatywy konsultował wielokrotnie z Janem Pawłem II, od którego otrzymywał błogosławieństwo do ich realizacji ${ }^{22}$, następnie zdawał relacje z podjętych zadań ${ }^{23}$. Papież cenił jego osobę i działalność ${ }^{24}$. Antoni Zięba nie budował wystąpień publicznych na socjotechnice i manipulacji emocjami. Był przekonany, iż dar wymowy i zjednywania słuchaczy w tematyce pro-life otrzymał jako specjalną łaskę od Boga, choć w skutecznej komunikacji z większym audytorium dopomogło mu również wieloletnie doświadczenie pracy dydaktycznej na uczelni ${ }^{25}$.

Zięba budował pozytywną komunikację szeroko pojętej problematyki bioetycznej. Ukazywał piękno rozwoju prenatalnego człowieka i nie szokował drastycznym przekazem przemocy prenatalnej. Wygłaszał liczne prelekcje w szkołach, na uniwersytetach, w sanktuariach, duszpasterstwach akademickich, docierając do młodzieży szkolnej, pracującej i akademickiej, rodziców, kapłanów, sióstr zakonnych, członków ruchów i stowarzyszeń

18 Por. T. Król, Inżynierski umysł dla życia, „Droga” (27 maja-9 czerwca 2018) nr 11, s. 12; D. Hybel, Wystarczy, że będziesz myślący, dz. cyt., s. 9; J. Kawecki, Inżynier Antoni Zięba, obrońca życia człowieka, nasz przyjaciel i współpracownik, dz. cyt., s. 17.

19 Por. M. Łącka, B. Gancarz, Fenomen Zięby, dz. cyt., s. 7.

20 Por. J. Kawecki, S. Pyrak, Śp. dr inż. Antoni Zięba (1948-2018), dz. cyt., s. 440; J. Kawecki, Inżynier Antoni Zięba, obrońca życia człowieka, nasz przyjaciel $i$ współpracownik, dz. cyt., s. 19.

21 Por. A. Zięba, Po 12 latach modlitwy stat się cud, dz. cyt., s. 46; M. Wilczek, Bądźmy wierni jego misji, „List do Pani” (czerwiec 2018) nr 6 (265), s. 6.

22 Por. J. Kawecki, S. Pyrak, Śp. dr inż. Antoni Zięba (1948-2018), dz. cyt., s. 440.

23 Por. M. Bochenek, Pozostanie wzorem, dz. cyt., s. 15.

24 Por. M. Bochenek, Apostoł nienarodzonych, „Nasz Dziennik” (5-6 maja 2018) nr 102 (6156), s. 2.

25 Por. D. Hybel, Wystarczy, że będziesz myślący, dz. cyt., s. 8; F. Ślusarczyk, Z wyobraźnia miłosierdzia, dz. cyt., s. 14. 
katolickich ${ }^{26}$. Przemawiał w większości seminariów duchownych i setkach kościołów na terenie całej Polski ${ }^{27}$. Podejmował dialog z parlamentarzystami, dziennikarzami, seksuologami i przedstawicielami środowisk proaborcyjnych. Gdy przedstawiano mu rzeczową i moralnie godziwą argumentację, potrafił wnikliwie słuchać i publicznie przyznać rację dyskutantom ${ }^{28}$. Środowiska feministyczne odmawiały jednak uczestnictwa w spotkaniach z jego udziałem, obawiając się konfrontacji z rzetelną argumentacją inż. Zięby, który podczas dyskusji z pamięci cytował najnowsze wyniki badań, publikowane w czasopismach naukowych o uznanej, międzynarodowej renomie, dotyczące procedury in vitro, aborcji, środków antykoncepcyjnych, permisywnej edukacji seksualnej, podając nie tylko szczegółowe dane, ale nawet autora, miejsce wydania i stronę cytowanej pracy naukowej ${ }^{29}$. Środowiska te jednak nie tylko nie chciały podejmować publicznej debaty z inż. Ziębą, ale wywierały silne naciski na uczelnie, aby te albo wykluczały go $\mathrm{z}$ grona prelegentów konferencji naukowych albo rezygnowały $\mathrm{z}$ ich organizacji. W grudniu 2017 roku lewicowa Partia Razem wymusiła na władzach Collegium Medicum Uniwersytetu Jagiellońskiego odwołanie XXVIII Konferencji Etycznej pt. „Etyka w medycynie - Prawo dziecka do życia”, która miała się odbyć w Uniwersyteckim Szpitalu Dziecięcym w Krakowie, tylko dlatego, że organizatorzy zaprosili Antoniego Ziębię do wygłoszenia referatu $^{30}$. Zwolennicy aborcji chcieli w ten sposób uniemożliwić kontakt obrońcy życia, doświadczonego nauczyciela akademickiego, ze studentami medycyny, położnictwa i pielęgniarstwa oraz personelem medycznym szpitala. Zięba stanowczo sprzeciwiał się „prostytucji intelektualnej”, przez którą rozumiał zaprzedanie się pracowników naukowych z tytułami profesorskimi w służbę ideologii, zwłaszcza aborcyjnej31. Pracownikom uniwersytetów i politykom, którzy negowali człowieczeństwo i status osobowy

\footnotetext{
26 Por. M. Guziak-Nowak, Inżynierze, dziękuję, dz. cyt., s. 33; A. Zięba, Po 12 latach modlitwy stat się cud, dz. cyt., s. 45.

27 Por. D. Hybel, Wystarczy, że będziesz myślacy, dz. cyt., s. 8.

28 Por. M. Guziak-Nowak, Inżynierze, dziękuję, dz. cyt., s. 33; S. Piętka OFMConv., "Kapłanie Boży” - w stuchawce telefonu, dz. cyt., s. 6.

29 Por. M. Guziak-Nowak, Inżynierze, dziękuje, dz. cyt., s. 33; T. Król, J. Tęcza-Ćwierz, Kim był śp. Antoni Zięba?, dz. cyt., s. 6; T. Król, Czuję sukces, „Źródło. Tygodnik Rodzin Katolickich" (27 maja 2018) nr 21 (1378), s. 12.

30 Por. M. Bochenek, Cenzura na życie, www.naszdziennik.pl/polska-kraj/192513,cenzura-na-zycie.html (07.02.2018).

31 Por. M. Guziak-Nowak, Inżynierze, dziękuje, dz. cyt., s. 33.
} 
embrionu ludzkiego, cytował podręczniki biologii dla szkół podstawowych jednoznacznie wskazujące na zapłodnienie gamety żeńskiej jako początek życia człowieka, chcąc przez to dowieść, iż wiedza ta jest dostępna uczniom już najniższych klas szkół powszechnych, a pracownicy szkół wyższych i parlamentarzyści kontestujący ten fakt medyczny dopuszczają się demagogii i ideologicznej manipulacji ${ }^{32}$.

Dorobek polskiego środowiska pro-life Antoni Zięba upowszechniał na zagranicznych kongresach i konferencjach ${ }^{33}$, i stał się jego reprezentantem, rozpoznawanym przez zagraniczne ośrodki. Organizował liczne wystawy, konferencje i sympozja poświęcone zagadnieniom bioetycznym i edukacyjno-wychowawczym, jak również dobroczynne koncerty na rzecz rodzin wielodzietnych czy wychowujących dzieci z niepełnosprawnością ${ }^{34}$. Współorganizował lokalne i ogólnopolskie marsze, których uczestnicy domagali się całkowitej delegalizacji aborcji, w tym zwłaszcza dwa Narodowe Marsze w Obronie Życia w 1996 roku $^{35}$. Był otwarty nie tylko na tradycyjne formy przekazu, jak prasa drukowana czy radio, ale także nowe technologie medialno-komunikacyjne ${ }^{36}$. Ze swoimi współpracownikami prowadził pierwszy w Polsce wideoblog pro-life (publikowany także na YouTube) ${ }^{37}$. Inspirował i kierował powstaniem wielu filmów o tematyce pro-life $e^{38}$. Wydawał w wielomilionowych nakładach materiały edukacyjne: broszury, foldery, plakaty, płyty $\mathrm{CD}^{39}$. Bezpłatnie przekazywał wydawnictwom krajowym i zagranicznym, fundacjom i bibliotekom licencje do wszystkich upowszechnianych

32 Por. M. Guziak-Nowak, Inżynierze, dziękuję, s. 33, dz. cyt.; T. Król, Czuję sukces, dz. cyt., s. 12 .

33 Por. T. Król, J. Tęcza-Ćwierz, Kim był śp. Antoni Zięba?, dz. cyt., s. 6; J. Sosnowska, Inżynier o gorejącym sercu misjonarza, dz. cyt., s. 71.

34 Por. T. Król, Inżynierski umysł dla życia, dz. cyt., s. 12; J. Sosnowska, Inżynier o gorejacym sercu misjonarza, dz. cyt., s. 71; M. Łącka, B. Gancarz, Fenomen Zięby, dz. cyt., s. 7.

35 Por. J. Kawecki, S. Pyrak, Śp. dr inż. Antoni Zięba (1948-2018), dz. cyt., s. 439; J. Sosnowska, Inżynier o gorejącym sercu misjonarza, dz. cyt., s. 70; T. Król, Inżynierski umysł dla $\dot{z} y c i a$, dz. cyt., s. 13; J. Kawecki, Inżynier Antoni Zięba obrońca życia człowieka, nasz przyjaciel i współpracownik, dz. cyt., s. 16.

36 Por. D. Hybel, Odszedł charyzmatyczny obrońca życia, dz. cyt., s. 9.

37 Por. T. Kancelarczyk, Wspomnienie - Mówiq o Inżynierze, „Niedziela” (20 maja 2018) nr 20, s. 18; D. Hybel, Wystarczy, że będziesz myślaccy, dz. cyt., s. 9; D. Hybel, Odszedł charyzmatyczny obrońca życia, dz. cyt., s. 4.

38 Por. M. Łącka, B. Gancarz, Fenomen Zięby, dz. cyt., s. 7.

39 Por. T. Król, Inżynierski umysł dla życia, dz. cyt., s. 12; J. Tęcza-Ćwierz, Uhonorowany za działalność pro-life, dz. cyt., s. 11; B. Falkowska, Testament obrony życia, dz. cyt., s. 3. 
przez jego stowarzyszenia opracowań, materiałów filmowych i wizualnych, zwłaszcza zdjęć ukazujących rozwój dziecka na kolejnych etapach wzrostu wewnątrzmacicznego ${ }^{40}$. Wniósł wkład w ustanowienie przez Sejm RP Narodowego Dnia Życia (24 marca) oraz w jego popularyzację ${ }^{41}$. Inicjował i koordynował doroczne obchody Narodowego Dnia Życia na uczelniach, w szkołach, bibliotekach i innych instytucjach publicznych, motywując także władze samorządowe do organizacji jego lokalnych obchodów. Pomimo szerokiej działalności publicznej i częstej obecności w mediach ogólnopolskich nie pozwolił wciągnąć się w bieżące rozgrywki polityczne. $Z$ rozmysłem dbał o to, aby nie stać się politykiem ani celebrytą, zaś w temacie obrony życia ludzkiego i ochrony młodzieży przed demoralizacją nie uznawał żadnych kompromisów, zwłaszcza politycznych ${ }^{42}$. Do końca pozostał obrońcą życia i działaczem katolickim. Jako patriota wysoko cenił niepodległość Polski, której suwerenność stanowiła dla niego pryncypialną wartość ${ }^{43}$. Sprzeciwiał się też postępującej laicyzacji społeczeństwa ${ }^{44}$.

Antoni Zięba posiadał nadzwyczajną umiejętność wytrwałego inicjowania i konsekwentnego realizowania kolejnych form działalności społecznej, którym nadawał różne struktury organizacyjne i formuły statutowe, oraz integrowania kręgów osób dla osiągania jasno określonych celów ${ }^{45}$. Przyznawane odznaczenia traktował jako wyróżnienie środowiska, które reprezentował, choć to on kształtował dynamikę jego aktywności

40 Por. T. Król, J. Tęcza-Ćwierz, Kim był śp. Antoni Zięba?, dz. cyt., s. 6; J. Kawecki, S. Pyrak, Śp. dr inż. Antoni Zięba (1948-2018), dz. cyt., s. 439; J. Tęcza-Ćwierz, Uhonorowany za działalność pro-life, dz. cyt., s. 11.

41 Por. M. Łącka, B. Gancarz, Fenomen Zięby, dz. cyt., s. 7.

42 Por. P. Wosicki, W temacie obrony życia-bezkompromisowy, dz. cyt., s. 24; J. A. Nalaskowski OSPPE, Śp. Antoni, nasz rycerzu, dziękujemy Ci za to, że byłeś wśród nas, dz. cyt., s. 26; J. Dulińska, Taki był Inżynier, „Źródło. Tygodnik Rodzin Katolickich” (27 maja 2018) nr 21 (1378), s. 10; T. Król, Czuję sukces, dz. cyt., s. 12.

43 Por. Redakcja, Do zobaczenia, Przyjacielu!, „Cuda i Łaski Boże” (czerwiec 2018) nr 6 (173), s. 2.

${ }_{44}$ Por. J. A. Nalaskowski OSPPE, Śp. Antoni, nasz rycerzu, dziękujemy Ci za to, że byłeś wśród nas, dz. cyt., s. 26.

45 Por. J. Kawecki, S. Pyrak, Śp. dr inż. Antoni Zięba (1948-2018), dz. cyt., s. 439; B. Falkowska, Testament obrońcy życia, dz. cyt., s. 3; S. Dziwisz, Bezkompromisowy obrońca życia, „Źródło. Tygodnik Rodzin Katolickich” (20 maja 2018) nr 20 (1377), s. 4; J. Kawecki, Inżynier Antoni Zięba, obrońca życia człowieka, nasz przyjaciel i współpracownik, dz. cyt., s. 18. 
i wyznaczał kierunki rozwoju ${ }^{46}$. Przez lata skład osobowy jego współpracowników ulegał zmianie, ale to Zięba stanowił trwały punkt odniesienia krakowskiego środowiska obrońców życia ${ }^{47}$. Jako człowiek zawierzania ufał, iż Opatrzność Boża zapewni środki na realizację nowych przedsięwzięć inicjowanych często bez kapitału wstępnego, co dotyczyło zwłaszcza powoływania kolejnych tytułów prasowych ${ }^{48}$. W pracy darzył wyjątkowym szacunkiem matki oczekujące potomstwa, wyrażając radość z poczęcia dziecka i stwarzając możliwie najdogodniejsze dla nich warunki pracy ${ }^{49}$. $\mathrm{Z}$ kolei pozbawione posady matki w ciąży lub po zakończonych urlopach wychowawczych zatrudniał w prowadzonych przez siebie organizacjach, pomagając im wrócić do zawodu lub wspierając w nauce nowego ${ }^{50}$. Dbał o rozwój zawodowy, formację intelektualną i duchową pracowników ${ }^{51}$. Troszczył się o ich życie rodzinne, traktując podwładnych po ojcowsku ${ }^{52}$. Do kobiet zwracał się w charakterystyczny dla siebie sposób: „niewiasto”, "córko"53. Sam pracował niemal do ostatnich dni, koordynując ze szpitala, a później z hospicjum działalność stowarzyszeń i projekty wydawnicze własnych redakcji prasowych, pozostając $\mathrm{w}$ stałym kontakcie z zespołami innych mediów katolickich i uzgadniając nowe zadania ${ }^{54}$.

46 Por. S. Mazurczak, Śp. Antoni Zięba - Stuga Życia 1948-2018, dz. cyt., s. 19; J. Tęcza-Ćwierz, Uhonorowany za działalność pro-life, dz. cyt., s. 9.

47 Por. R Michalik, Ocalał życie bezbronnych, dz. cyt., s. 30.

48 Por. M. Guziak-Nowak, Inżynierze, dziękuję, dz. cyt., s. 34; K. Gałuszka (a), Nauczyt mnie zachwytu nad życiem, „Źródło. Tygodnik Rodzin Katolickich”, (20 maja 2018) nr 20 (1377), s. 13; P. Wosicki, W temacie obrony życia - bezkompromisowy, dz. cyt., s. 24.

49 Por. B. Kawecka, Umiał mobilizować i zachęcać do współpracy, „Źródło. Tygodnik Rodzin Katolickich", (20 maja 2018) nr 20 (1377), s. 27; M. Łącka, B. Gancarz, Fenomen Zięby, dz. cyt., s. 7; M. Guziak-Nowak, Inżynierze, dziękuję, dz. cyt., s. 34; A. Kisiel, Antoni Zięba - dobry przyjaciel, „Źródło. Tygodnik Rodzin Katolickich” (20 maja 2018) nr 20 (1377), s. 5; J. Dulińska, Taki był Inżynier, dz. cyt., s. 10.

50 Por. B. Kawecka, Umiał mobilizować i zachęcać do wspótpracy, dz. cyt., s. 27.

51 Por. T. Król, J. Tęcza-Ćwierz, Kim był śp. Antoni Zięba?, dz. cyt., s. 5.

52 Por. M. Łącka, B. Gancarz, Fenomen Zięby, dz. cyt., s. 7.

53 Por. J. Dulińska, Taki był Inżynier, dz. cyt., s. 10.

54 Por. L. Dudkiewicz, Mistrz w sztafecie obrony życia, „Niedziela” (20 maja 2018) nr 20, s. 14; M. Wilczek, Bądźmy wierni jego misji, dz. cyt., s. 6; T. Król, J. Tęcza-Ćwierz, Kim byt śp. Antoni Zięba?, dz. cyt., s. 6; M. Guziak-Nowak, Inżynierze, dziękuję, dz. cyt., s. 34. 


\section{Fenomen duchowości}

Antoni Zięba nie był inkwizytorem ${ }^{55}$. Potępiał zło, ale nie odrzucał osób, które zło czyniły lub propagowały, nie gorszył się nimi ${ }^{56}$. Doświadczenie grzechu mobilizowało go do jeszcze intensywniejszej modlitwy za osoby nim dotknięte ${ }^{57}$. Uważał, że w perspektywie zbrodni aborcji dokonanej na 20 milionach dzieci w okresie obowiązywania stalinowskiej ustawy aborcyjnej z 1956 roku Bóg przygotował polskiemu społeczeństwu specjalną łaskę, która może wyeliminować społeczne, moralne i duchowe skutki tego zła, jednak to od narodu zależy, czy zechce tę łaskę przyjąć i podjąć pokutę ${ }^{58}$. Swoje stanowisko potwierdzał nauczaniem św. Pawła z listu do Rzymian: "Gdzie wzmógł się grzech, tam jeszcze obficiej rozlała się łaska” (Rz 5,20). Wzorem strategii zwyciężania zła dobrem stał się dla niego bł. ks. Jerzy Popiełuszko, dlatego Zięba nie odpowiadał negatywnie na liczne próby odbierania mu dobrego imienia, stygmatyzowania i marginalizowania, $w$ tym również na przemoc słowną środowisk proaborcyjnych i jeszcze boleśniejsze ataki środowisk katolickich czy przypadki niezrozumienia lub odmowy współpracy ze strony duchowieństwa ${ }^{59}$. Z cierpliwością znosił zarówno zarzuty o tworzenie podziałów, jak i brak gotowości do pojednania w polskim środowisku pro-life, broniąc stanowiska episkopatu w sprawie niekaralności kobiet po przeprowadzonej aborcji ${ }^{60}$. Nie prowadził spraw sądowych przeciw adwersarzom. Był świadom, że skierowane przeciw niemu ataki są częścią historiozbawczego zmagania się życia i śmierci, dobra ze złem, którego pojedyncze osoby i poszczególne środowiska pozwoliły się uczynić narzędziami ${ }^{61}$. Często powtarzał „walka za nami i walka przed nami” ${ }^{62}$, lecz nie

\footnotetext{
55 Por. J. Sosnowska, Inżynier o gorejącym sercu misjonarza, dz. cyt., s. 71.

56 Por. T. Król, J. Tęcza-Ćwierz, Kim byt śp. Antoni Zięba?, dz. cyt., s. 5.

57 Por. A. Zięba, Po 12 latach modlitwy stat się cud, dz. cyt., s. 49; D. Raś, Śladami patrona, „Źródło. Tygodnik Rodzin Katolickich” (20 maja 2018) nr 20 (1377), s. 28.

58 Por. M. Cichoń, Jak Inżynier został obrońca życia, dz. cyt., s. 26.

59 Por. Redakcja, Do zobaczenia, Przyjacielu!, dz. cyt., s. 3.

60 Por. M. Guziak-Nowak, Inżynierze, dziękuję, dz. cyt., s. 33; K. Kratiuk, Wyznawcy kompromisów. Kulisy odrzucenia projektu „Stop Aborcji”, Kraków 2017 (Biblioteka Polonia Christiana); A. Zięba, O podziale wśród obrońców życia, „Źródło. Tygodnik Rodzin Katolickich" (8 stycznia 2017) nr 2 (1306), s. 11.

61 Por. F. Ślusarczyk, Z wyobraźnią miłosierdzia, dz. cyt., s. 14.

62 Przytoczony cytat jest fragmentem wiersza pt. Pożegnanie przyjaciela Krzysztofa Konstantego Stypuły. Por. J. Kawecki, Inżynier Antoni Zięba, obrońca życia człowieka, nasz przyjaciel i wspótpracownik, dz. cyt., s. 20.
} 
przeciw komuś, ale przeciw złu ${ }^{63}$. Żywił głębokie przekonanie, iż obrońcom życia towarzyszy specjalne błogosławieństwo tożsame z tym, jakim Bóg otaczał egipskie położne, które asystując przy porodach hebrajskich kobiet, nie pozbawiały życia nowonarodzonych żydowskich chłopców wbrew zaleceniu faraona (Wj 1,15-22) ${ }^{64}$. Wielokrotnie powoływał się na słowa autora natchnionego Księgi Wyjścia: „Bóg dobrze czynił położnym” (Wj 1,20). Równocześnie zdawał sobie w pełni sprawę z tego, iż odpowiedzialność za nieprzyjęty dar życia ciąży nie tylko na tych, którzy dopuścili się zła uśmiercenia dziecka, ale także na tych, którzy zaniedbali czynić dobra ${ }^{65}$. Przykładał zatem najwyższą wagę do wychowania młodego pokolenia do czystości, podejmując starania o wprowadzenie, a następnie utrzymanie w polskich szkołach edukacji seksualnej typu A w formie zajęć dydaktycznych w ramach przedmiotu wychowania do życia w rodzinie oraz rozwijał katolicką prasę dla dzieci i młodzieży, jak również profesjonalne czasopismo popularnonaukowe dla pedagogów, nauczycieli i rodziców ${ }^{66}$.

Dzień rozpoczynał od modlitwy trwającej przynajmniej jedną godzinę. Oddawał się lekturze Pisma Świętego, zwłaszcza Dziejów Apostolskich, Księgi Psalmów czy perykopy ewangelicznej przypadającej w danym dniu. Medytacja tekstów biblijnych stanowiła dla niego również formę odpoczynku. Nosił przy sobie wybrane fragmenty Pisma Świętego, a jego ulubioną modlitwą były litanie. Z zasady odmawiał trzy, w tym zawsze do Ducha Świętego i Matki Bożej. Dużą wagę przywiązywał do aktów strzelistych. W jego plan dnia wpisana była także modlitwa różańcowa i koronka do Miłosierdzia Bożego. Dochowywał wierności codziennego udziału we mszy świętej. Wzór modlitwy czerpał od Jana Pawła II i św. Maksymiliana Kolbego, których uważał za swoich ojców duchowych. Zgodnie z ich wskazaniem uznawał modlitwę za pierwszorzędne i najważniejsze zadanie. Jej zaniedbanie, w jego opinii, prowadziło do pustego zewnętrznego aktywizmu i ostatecznie dezintegrowało podjęte wysiłki, toteż czuł się odpowiedzialny

\footnotetext{
63 Por. Redakcja, Do zobaczenia, Przyjacielu!, dz. cyt., s. 3; E. Staniek, Charyzmatyk, dz. cyt., s. 8; F. Ślusarczyk, Z wyobraźniq miłosierdzia, dz. cyt., s. 14.

64 Por. M. Cichoń, Jak Inżynier został obrońca życia, dz. cyt., s. 27.

65 Por. M. Cichoń, Jak Inżynier został obrońca życia, dz. cyt., s. 27.

66 Por. J. Tęcza-Ćwierz, Uhonorowany za działalność pro-life, dz. cyt., s. 11; T. Król, J. Tęcza-Ćwierz, Kim był śp. Antoni Zięba?, dz. cyt., s. 6; T. Król, Inżynierski umysł dla życia, dz. cyt., s. 12; J. Kawecki, Inżynier Antoni Zięba, obrońca życia człowieka, nasz przyjaciel i współpracownik, dz. cyt., s. 17; T. Król, Czuję sukces, dz. cyt., s. 12.
} 
za propagowanie zobowiązania do modlitwy ${ }^{67}$. Szczególnym kultem otaczał także swojego patrona, św. Antoniego, z Kaplicy Złoczyńców Bazyliki Mariackiej w Krakowie ${ }^{68}$.

Zięba nigdy nie prosił o modlitwę za siebie, a dopytującym o jego stan zdrowia polecał pamięci modlitewnej swoje chore wnuczęta. Pomimo postępującej choroby nowotworowej i utraty sił ofiarnie pełnił przy nich nocne dyżury w szpitalach lub w domu, wbrew zmęczeniu nie tracąc pogody ducha ${ }^{69}$. Na bolesne zmagania $z$ chorobą wnucząt potrafił spojrzeć z perspektywy wiary jako na doświadczenia pozytywne, niezwykle silnie jednoczące rodzinę ${ }^{70}$. Szczególnie troszczył się o rozwój miłości i pogłębienie wzajemnych relacji w małżeństwie i rodzinie ${ }^{71}$. Własne małżeństwo uznawał za szczęśliwe ${ }^{72}$. Roztaczał opiekę również nad biednymi, matkami w ciąży, rodzinami wielodzietnymi, rodzinami z dziećmi upośledzonymi, osobami z niepełnosprawnością i sierotami, dla których nie tylko zorganizował system pomocy finansowej w ramach prowadzonych stowarzyszeń i fundacji, ale których wspierał materialnie także z własnej pensji, gdy zaszła taka potrzeba ${ }^{73}$. Cechowały go zadziwiające w kontekście pokonywanych trudności i choroby nowotworowej entuzjazm wiary i radość życia, którymi obdarzał otoczenie.

Wyróżniał się nadzwyczajną miłością do Kościoła i heroicznym wręcz posłuszeństwem wobec duchowieństwa ${ }^{74}$. Oficjalne stanowisko Konferencji Episkopatu Polski czynił swoim, choćby jego osobiste zdanie było odmienne ${ }^{75}$. W publicznych wystąpieniach i prywatnych dyskusjach wspierał

67 Por. D. Hybel, Wystarczy, że będziesz myślący, dz. cyt., s. 9; D. Hybel, Odszedł charyzmatyczny obrońca życia, dz. cyt., s. 4; M. Łącka, B. Gancarz, Fenomen Zięby, dz. cyt., s. 7; A. Zięba, Po 12 latach modlitwy stał się cud, dz. cyt., s. 46; S. Piętka OFMConv., „Kapłanie Boży” - w stuchawce telefonu, dz. cyt., s. 6; J. Dąbrowski, Panie, nie pytam, dlaczego go zabrałeś, lecz dziękuję za to, że nam go dałeś, dz. cyt., s. 8.

68 Por. D. Raś, Śladami patrona, dz. cyt., s. 28.

69 Por. M. Wilczek, Bądźmy wierni jego misji, dz. cyt., s. 6; K. Gałuszka (a), Nauczył mnie zachwytu nad życiem, dz. cyt., s. 13.

70 Por. M. Cichoń, Jak Inżynier został obrońca życia, dz. cyt., s. 26.

71 Por. S. Dziwisz, Bezkompromisowy obrońca życia, dz. cyt., s. 4.

72 Por. J. Tęcza-Ćwierz, Uhonorowany za działalność pro-life, dz. cyt., s. 10.

73 Por. A. Kisiel, Antoni Zięba - dobry przyjaciel, dz. cyt., s. 5; J. Kawecki, Inżynier Antoni Zięba, obrońca życia człowieka, nasz przyjaciel i współpracownik, dz. cyt., s. 18.

74 Por. S. Piętka, „Kapłanie Boży” - w słuchawce telefonu, dz. cyt., s. 6; D. Raś, Śladami patrona, dz. cyt., s. 28.

75 Por. M. Łącka, B. Gancarz, Fenomen Zięby, dz. cyt., s. 7. 
orzeczenia biskupów. Nie krytykował publicznie Kościoła i z najwyższym szacunkiem odnosił się do duchownych i osób życia konsekrowanego, nierzadko młodszych od siebie lub negatywnie oceniających jego działalność ${ }^{76}$. Jeśli uważał to za konieczne, wówczas krytyczne opinie wyrażał $\mathrm{w}$ bezpośredniej rozmowie $\mathrm{z}$ danym hierarchą lub kapłanem, jednak bez obecności osób trzecich. Sądził, że w sprawach organizacji danego przedsięwzięcia ostatni głos należy do kapłana i to on jest decydujący. Do księży zwracał się specyficznym dla siebie życzliwym pozdrowieniem: „Witam kapłana Bożego"77. Postawy wierności i posłuszeństwa Kościołowi uczył też swoich współpracowników. O roli Eucharystii w jego życiu i osobistej czci dla kapłaństwa służebnego świadczy fakt, iż z wdzięczności całował po rękach księdza sprawującego mszę świętą, kiedy przebywał w hospicjum ${ }^{78}$. $\mathrm{Z}$ pietyzmem przyjmował komunię święta, zawsze w postawie klęczącej ${ }^{79}$. W jednym z wywiadów stwierdził: „Obrońca życia powinien mieć statutowy obowiązek miłości do Chrystusa, który jest dawcą życia" ${ }^{30}$.

Niespełna pół roku przed śmiercią, jesienią 2017 roku, w obliczu postępującej choroby nowotworowej za radą kard. Stanisława Dziwisza inż. Zięba udał się z pielgrzymką do grobu św. Jana Pawła II na Watykanie. Wyprosił dla siebie łaskę nieodczuwania bólu powodowanego zaawansowanym nowotworem ${ }^{81}$. Był jednak gotów przyjąć cierpienie, jeśli taka będzie wola Boża, choć się go obawiał ${ }^{82}$. Nie bał się natomiast samej śmierci, którą traktował jako wyjście na spotkanie „Dawcy życia i Zwycięzcy śmierci”"33. W swoim ostatnim publicznym wystąpieniu przyznał: „Mam nadzieję na wieczność z Chrystusem"84. Do ostatnich dni spędzonych w hospicjum zachowywał

\footnotetext{
76 Por. M. Guziak-Nowak, Inżynierze, dziękuje, dz. cyt., s. 33.

77 Por. S. M. Piętka, „Kapłanie Boży” - w słuchawce telefonu, dz. cyt., s. 6; T. Kancelarczyk, Ikona ruchu pro-life, „Źródło. Tygodnik Rodzin Katolickich” (27 maja 2018) nr 21 (1378), s. 11; F. Ślusarczyk, Z wyobraźniq miłosierdzia, dz. cyt., s. 14; S. Jarosz, Zawierzał siebie i dzieło obrony życia poczętych dzieci Pani Jasnogórskiej, „Źródło. Tygodnik Rodzin Katolickich" (20 maja 2018) nr 20 (1377), s. 31.

78 Por. M. Guziak-Nowak, Inżynierze, dziękuje, dz. cyt., s. 34.

79 Por. J. A. Nalaskowski, Śp. Antoni, nasz rycerzu, dziękujemy Ci za to, że byłeś wśród nas, dz. cyt., s. 27.

80 D. Hybel, Wystarczy, że będziesz myślący, dz. cyt., s. 9.

81 Por. L. Dudkiewicz, Mistrz w sztafecie obrony życia, dz. cyt., s. 14; B. Falkowska, Testament obrońcy życia, dz. cyt., s. 3; M. Łącka, B. Gancarz, Fenomen Zięby, dz. cyt., s. 7.

82 Por. M. Cichoń, Odszedł wielki obrońca życia, dz. cyt., s. 16.

83 Por. M. Cichoń, Odszedł wielki obrońca życia, dz. cyt., s. 16.

84 Cyt. za: S. Dziwisz, Bezkompromisowy obrońca życia, dz. cyt., s. 4.
} 
dobrą kondycję fizyczną i jeszcze lepszą psychiczną, budząc zdumienie personelu medycznego. Żywił głębokie przekonanie, iż łaskę tę należy przypisać wstawiennictwu św. Jana Pawła II i sile modlitwy ${ }^{85}$. Odchodził świadomie. Pragnął przed śmiercią pożegnać swoich współpracowników, dlatego telefonował do redakcji mediów katolickich, kapłanów, biskupów, działaczy pro-life i w trakcie rozmowy, żegnając się, czynił podsumowania, dziękował za wspólną pracę ${ }^{86}$. W gronie jego współpracowników żywe jest przekonanie, iż swoje życie złożył w ofierze w intencji uchwalenia przez polski parlament prawnej gwarancji ochrony życia ludzkiego od poczęcia do naturalnej śmierci bez jakiegokolwiek wyjątku ${ }^{87}$.

O uzdrowienie Antoniego Zięby z choroby nowotworowej modliło się wiele osób. Należy jednak stwierdzić, że choć to upragnione uzdrowienie nie nadeszło, to odjęcie cierpienia u osoby chorującej na jedną z najboleśniejszych postaci nowotworu (kości) jest wyraźnym znakiem działania Bożego, jeszcze większym niż byłby nim sam fakt uzdrowienia fizycznego. Znane są w historii Kościoła przypadki osób wyniesionych przez Boga na wysokie stopnie świętości, których ciała zostały zachowane od pośmiertnego rozkładu ze względu na pielęgnowaną za życia czystość, jak wizjonerki objawień lourdzkich św. Bernadety Soubirous, lub dla których Eucharystia stanowiła przez kilkadziesiąt lat jedyne źródło pokarmu, czego przykładem jest stygmatyczka Marta Robin. Dokładna analiza życia wewnętrznego Antoniego Zięby na podstawie pozostawionych pism i relacji świadków jego rozwoju duchowego pozwoli odpowiedzieć na pytanie, czy wyróżniająca go do końca życia niebywała wręcz radość z bliskiego spotkania Chrystusa w wieczności, towarzysząca nieuchronnie zbliżającej się śmierci, oraz uwolnienie go od fizycznego bólu choroby nowotworowej pomimo wyniszczenia ciała stanowią potwierdzenie przez Opatrzność jego osobistej czystości i świętości życia. Na tę postawę radosnego oczekiwania na śmierć wskazał w homilii pogrzebowej metropolita krakowski, abp Marek Jędraszewski: „Wiedział, że zbliża się kres jego ziemskiej wędrówki, ale szedł na spotkanie

\footnotetext{
85 Por. M. Guziak-Nowak, Inżynierze, dziękuję, dz. cyt., s. 33.

86 Por. I. Skubiś, Śp. dr inż. Antoni Zięba - Obrońca Życia i Świadek Zmartwychwstania, „Niedziela” (13 maja 2018) nr 19, s. 3; S. Piętka, „Kapłanie Boży” - w słuchawce telefonu, dz. cyt., s. 7; F. Płonka, Człowiek wyjątkowej wiary i wyjątkowego czynu, „Źródło. Tygodnik Rodzin Katolickich" (20 maja 2018) nr 20 (1377), s. 29.

87 Por. I. Skubiś, Śp. dr inż. Antoni Zięba - Obrońca Życia i Świadek Zmartwychwstania, dz. cyt., s. 3; B. Falkowska, Testament obrony życia, dz. cyt., s. 1.
} 
z Bogiem pełen nadziei, wiary i radości tak niezwykłej, że stała się ona nie tylko dla współobecnych dzielących razem z nim ten sam pokój w Hospicjum św. Łazarza, ale także dla personelu i dla innych ludzi znakiem głębokiej wiary w to, że po dobrym życiu Chrystus przyjmie go do swego Królestwa"88. Prezes Polskiej Federacji Ruchów Obrony Życia, Paweł Wosicki, w pośmiertnym wspomnieniu wieloletniego współpracownika i przyjaciela jednoznacznie zaświadczył, iż dla Antoniego Zięby „perspektywa życia wiecznego była czymś oszałamiającym"89.

Pośród wyróżniających się cech duchowości inż. Zięby widoczne są m.in.:

- autentyczna wiara rodząca chrześcijańską nadzieję na zmartwychwstanie i radość z przyszłego życia wiecznego, będące konsekwencją traktowania Boga jako żywej Osoby i nawiązania z nim zażyłej relacji oraz afirmacji prawdy o powołaniu człowieka do komunijnego zjednoczenia $\mathrm{z}$ Bogiem po śmierci;

- dojrzała miłość przeżywana w małżeństwie, wyrażająca się w relacji rodzicielskiej i objawiająca się $\mathrm{w}$ duchowym ojcostwie realizowanym wobec dzieci jeszcze nienarodzonych;

- wytrwałość we własnej formacji prawego sumienia i troska o uchronienie sumień innych osób od ich deprawacji;

- oparcie wiary na solidnej formacji intelektualnej (wiara poszukująca zrozumienia);

- uznanie działalności pro-life nie jako własny projekt życia, lecz jako powołanie otrzymane od Boga i jego konsekwentne wypełnienie;

- zmysł eklezjalny, czyli głębokie zrozumienie natury Kościoła, jego władzy duchowej i hierarchicznej struktury wymagającej zachowania posłuszeństwa, a także dochowanie tego posłuszeństwa w stopniu niejednokrotnie przewyższającym postawy wielu kapłanów;

- głęboki szacunek dla ludzkiej prokreacji jako tego wymiaru człowieczeństwa, w którym szczególnie ujawnia się podobieństwo osoby ludzkiej do Boga jako Stwórcy;

88 Cyt. za: Redakcja, Świadek Ewangelii Życia, „Źródło. Tygodnik Rodzin Katolickich” (20 maja 2018) nr 20 (1377), s. 22.

89 P. Wosicki, Strata Przyjaciela i Mistrza, „Głos dla Życia” (maj-czerwiec 2018) nr 3 (152), s. 5. 
- głębokie zakorzenienie w rzeczywistości społecznej i realiach życia własnej epoki, odczytanie głównych jej błędów i umiejętność przedsięwzięcia środków zaradczych (przede wszystkim natury duchowej); nieuciekanie od świata, lecz aktywne jego przekształcanie zgodnie z zamysłem Bożym poprzez budowanie szacunku dla daru życia i otwartości na jego przyjęcie;

- autentyczna radość życia i obdarowywanie nią innych, odrzucenie sceptycyzmu, nihilizmu, dekadencji; postrzeganie doświadczenia zła przez pryzmat uzdrawiającej łaski;

- głęboka cześć dla Eucharystii i niezłomna wiara w obecność Chrystusa w znakach sakramentalnych, z czego wynikała staranna troska o regularność życia sakramentalnego;

- usytuowanie Eucharystii, osobistej modlitwy i medytacji Pisma Świętego w centrum codziennego życia duchowego;

- uznanie modlitwy za źródło i warunek wszelkiej działalności, niewzruszona wiara w siłę modlitwy, umiłowanie modlitwy wstawienniczej;

- szczególne zrozumienie wartości pokuty i wynagrodzenia Bogu za popełnione zło oraz dziękczynienia za otrzymane dobro;

- głęboka i zdrowa pobożność maryjna;

- wytrwałe nabożeństwo do Ducha Świętego i otwartość na jego natchnienia, zwłaszcza w rozpoznawaniu znaków czasu;

- postawa zawierzenia i ufności w Opatrzność Bożą, postrzeganie trudnych wydarzeń życiowych przez pryzmat realizacji woli Bożej, przyjęcie cierpienia najbliższych osób bez sprzeciwu i buntu wobec Boga, przeżywanie własnej choroby prowadzącej do śmierci z całkowitym poddaniem się zamiarom Bożym;

- miłość nieprzyjaciól, odrzucenie prawa odwetu, cierpliwe znoszenie krzywd i niesłusznej krytyki oraz umiejętność ofiarowania ich w intencji dzieci rozwijających się w łonach matek;

- konsekwentna aplikacja we własnym życiu wzoru życia chrześcijańskiego wybranych patronów rozwoju duchowego: św. Maksymiliana Marii Kolbego, św. Antoniego z Padwy, bł. ks. Jerzego Popiełuszki, św. Jana Pawła II.

Prowadząc szeroką działalność społeczną, Antoni Zięba spotykał się wielokrotnie z niesłuszną krytyką. Zarzuty te były najczęściej wysuwane bądź przez środowiska wrogie Kościołowi i otwarcie domagające się szerokiego 
dostępu do różnych form przemocy prenatalnej i ich depenalizacji, bądź przez osoby, dla których publiczne podejmowanie problemu aborcji rodziło wyrzuty sumienia, jak również przez osoby uważające się za wierzące, ale niezaangażowane w życie Kościoła i odznaczające się postawami antyklerykalnymi, a także przez osoby utożsamiające się z Kościołem, ale nierozumiejące wagi podejmowanych przez inż. Ziębę problemów bioetyczno-wychowawczych i bagatelizujące ich znaczenie, wreszcie przez środowiska określające się jako katolickie, jednak często nieposłuszne Kościołowi hierarchicznemu, jak ukazała to prowadzona od 2014 roku dyskusja wewnątrz polskiego środowiska pro-life w sprawie karalności kobiet dopuszczających się aborcji i wielość zgłoszonych do kancelarii Marszałka Sejmu w VIII kadencji parlamentu obywatelskich projektów ustaw znoszących dostępność aborcji. Dla jednej grupy krytyków Antoni Zięba był skrajnie radykalnym fundamentalistą łamiącym prawa kobiet (przez które rozumiano prawo do aborcji, antykoncepcji, środków wczesnoporonnych itp.) i bezprawnie naruszającym ich autonomię sumienia, dla drugiej grupy osobą dewocyjną ślepo zapatrzoną w Kościół, z kolei dla trzeciej nazbyt liberalnym działaczem pro-life udaremniającym skuteczną obronę życia ludzkiego przez odrzucenie karalności kobiet za przeprowadzenie aborcji i krytykę publicznej ekspozycji zwłok abortowanych dzieci. Tymczasem inż. Zięba stał zawsze na tym samym stanowisku, co Kościół hierarchiczny ${ }^{90}$.

\section{Podsumowanie}

Fenomen działalności pro-life i duchowości Antoniego Zięby nie przejawia się wyłącznie w cechach jego osobowości i charakteru, liczbie zrealizowanych projektów edukacyjnych, skutecznej komunikacji w wystąpieniach publicznych czy sprawności organizacyjnej. Choć nie można umniejszać znaczenia rezultatów społecznego zaangażowania inż. Zięby w dzieło obrony życia ludzkiego i integralności rodziny, to należy jednak zważyć, iż stanowią one zaledwie zewnętrzną egzemplifikację jego wewnętrznej realizacji powołania chrześcijańskiego jako męża, ojca i obrońcy życia w stopniu nadzwyczajnym, uzyskania wysokiego stopnia cnót teologalnych oraz miłosierdzia

90 Por. A. Zięba, O podziale wśród obrońców życia, dz. cyt., s. 11. 
pełnionego przez konkretny czyn, głoszone słowo i wytrwałą modlitwę, zgodnie z trzema sposobami świadczenia miłosierdzia podanymi przez Chrystusa siostrze Faustynie Kowalskiej ${ }^{91}$.

\section{Bibliografia}

Bochenek M., Apostoł nienarodzonych, „Nasz Dziennik” (5-6 maja 2018) nr 102 (6156), s. 2.

Bochenek M., Pozostanie wzorem, „Nasz Dziennik” (9 maja 2018) nr 105 (6159), s. 15.

Cichoń M., Jak inżynier został obrońca życia, „Niedziela” (8 kwietnia 2018) nr 14, s. 26-27.

Cichoń M., Odszedł wielki obrońca życia, „Niedziela” (13 maja 2018) nr 19, s. $16-17$.

Dąbrowski J., Panie, nie pytam, dlaczego go zabrateś, lecz dziękuje za to, że nam go dałeś, „Źródło. Tygodnik Rodzin Katolickich” (27 maja 2018) nr 21 (1378), s. 8-9.

Dudkiewicz L., Mistrz w sztafecie obrony życia, „Niedziela” (20 maja 2018) nr 20, s. 14.

Dulińska J., Taki był Inżynier, „Źródło. Tygodnik Rodzin Katolickich” (27 maja 2018) nr 21 (1378), s. 10.

Dziwisz S., Bezkompromisowy obrońca życia, „Źródło. Tygodnik Rodzin Katolickich" (20 maja 2018) nr 20 (1377), s. 4.

Falkowska B., Testament obrońcy życia, „Nasz Dziennik” (5-6 maja 2018) nr 102 (6156), s. 1, 3.

Gałuszka K. (a), Nauczył mnie zachwytu nad życiem, „Źródło. Tygodnik Rodzin Katolickich" (20 maja 2018) nr 20 (1377), s. 12-13.

Gałuszka K. (b), Nauczył mnie zachwytu nad życiem, „Nasza Arka” (2018) nr 6 (210), s. 20-22.

Guziak-Nowak M., Inżynierze, dzięeuje, „Przewodnik Katolicki” (13 maja 2018) nr 19, s. 32-34.

91 Por. F. Kowalska, Dzienniczek. Miłosierdzie Boże w duszy mojej, Warszawa 2007, s. 296 (nr 742); F. Ślusarczyk, Z wyobraźnią miłosierdzia, dz. cyt., s. 14. 
Hybel D., Jubileusz 25 lat w służbie życia i rodziny Polskiej Federacji Ruchów Obrony Życia, „Głos dla Życia” (maj-czerwiec 2018) nr 3 (152), s. 14-16. Hybel D., Odszedł charyzmatyczny obrońca życia, „Głos dla Życia” (majczerwiec 2018) nr 3 (152), s. 4.

Hybel D., Wystarczy, że będziesz myślacy, „Głos dla Życia” (maj-czerwiec 2018) nr 3 (152), s. 8-9.

Jarosz OSPPE S., Zawierzat siebie i dzieło obrony życia poczętych dzieci Pani Jasnogórskiej, „Źródło. Tygodnik Rodzin Katolickich” (20 maja 2018) nr 20 (1377), s. 31.

Kancelarczyk T., Ikona ruchu pro-life, „Źródło. Tygodnik Rodzin Katolickich” (27 maja 2018) nr 21 (1378), s. 11.

Kancelarczyk T., Wspomnienie - Mówią o Inżynierze, „Niedziela” (20 maja 2018) $\mathrm{nr} 20$, s. 18.

Kawecka B., Umiat mobilizować i zachęcać do wspótpracy, „Źródło. Tygodnik Rodzin Katolickich" (20 maja 2018) nr 20 (1377), s. 27.

Kawecki J., Inżynier Antoni Zięba, obrońca życia człowieka, nasz przyjaciel $i$ wspótpracownik, „Źródło. Tygodnik Rodzin Katolickich” (20 maja 2018) nr 20 (1377), s. 15-20.

Kawecki J., Pyrak S., Śp. dr inż. Antoni Zięba (1948-2018), „Inżynieria i Budownictwo" nr 7-8 (2018), s. 438-440.

Kisiel A., Antoni Zięba - dobry przyjaciel, „Źródło. Tygodnik Rodzin Katolickich" (20 maja 2018) nr 20 (1377), s. 5.

Kisiel A., Krucjata Modlitwy w Obronie Poczętych Dzieci, „Służba Życiu. Zeszyty Problemowe" 2 (2008), s. 17-19.

Kowalska F., Dzienniczek. Miłosierdzie Boże w duszy mojej, Warszawa 2007.

Kratiuk K., Wyznawcy kompromisów. Kulisy odrzucenia projektu „Stop Aborcji”, , Kraków 2017 (Biblioteka Polonia Christiana).

Król T., Czuje sukces, „Źródło. Tygodnik Rodzin Katolickich” (27 maja 2018) nr 21 (1378), s. 12.

Król T., Inżynierski umysł dla życia, „Droga” (27 maja-9 czerwca 2018) nr 11, s. 12-13.

Król T., Tęcza-Ćwierz J., Kim byt śp. Antoni Zięba?, „Wychowawca” (czerwiec 2018) nr 6 (302), s. 5-6.

Łącka M., Gancarz B., Fenomen Zięby, „Gość Niedzielny” (20 maja 2018) nr 20, s. 6-7. 
Mazurczak S., Śp. Antoni Zięba - Stuga Życia 1948-2018, „W Naszej Rodzinie" (czerwiec 2018) nr 6 (101), s. 19.

Michalik R., Ocalał życie bezbronnych, „Źródło. Tygodnik Rodzin Katolickich" (20 maja 2018) 20 (1377), s. 30.

Nalaskowski OSPPE J. A., Śp. Antoni, nasz rycerzu, dziękujemy Ci za to, że byłeś wśród nas, „Źródło. Tygodnik Rodzin Katolickich” (20 maja 2018) nr 20 (1377), s. 26-27.

Piętka OFMConv. S. M., „Kapłanie Boży” - w stuchawce telefonu, „Źródło. Tygodnik Rodzin Katolickich" (20 maja 2018) nr 20 (1377), s. 6-7.

Płonka F., Człowiek wyjątkowej wiary i wyjątkowego czynu, „Źródło. Tygodnik Rodzin Katolickich" (20 maja 2018) nr 20 (1377), s. 29.

Puścikowska A., Zmarł działacz pro-life, „Gość Niedzielny” (13 maja 2018) nr 19, s. 13.

Raś D., Śladami patrona, „Źródło. Tygodnik Rodzin Katolickich” (20 maja 2018) nr 20 (1377), s. 28.

Redakcja, Do zobaczenia, Przyjacielu!, „Cuda i Łaski Boże” (czerwiec 2018) nr 6 (173), s. 2-3.

Redakcja, Świadek Ewangelii Życia, „Źródło. Tygodnik Rodzin Katolickich” (20 maja 2018) nr 20 (1377), s. 22-23.

Skubiś I., Śp. dr inż. Antoni Zięba - Obrońca Życia i Świadek Zmartwychwstania, „Niedziela” (13 maja 2018) nr 19, s. 3.

Sosnowska J., Inżynier o gorejacym sercu misjonarza, „WPIS” (25 kwietnia-23 maja 2018) nr 4 (90), s. 70-72.

Sprawozdanie merytoryczne z działalności Polskiego Stowarzyszenia Obrońców Życia Człowieka w Krakowie za rok 2017.

Staniek E., Charyzmatyk, „Źródło. Tygodnik Rodzin Katolickich” (20 maja 2018) nr 20 (1377), s. 7-8.

Statut Polskiego Stowarzyszenia Nauczycieli i Wychowawców w Krakowie, Sprawozdanie z działalności Polskiego Stowarzyszenie Nauczycieli i Wychowawców za rok 2016.

Ślusarczyk F., Z wyobraźnia miłosierdzia, „Źródło. Tygodnik Rodzin Katolickich" (20 maja 2018) nr 20 (1377), s. 14.

Tęcza-Ćwierz J., Uhonorowany za działalność pro-life, „Źródło. Tygodnik Rodzin Katolickich" (20 maja 2018) nr 20 (1377), s. 9-11.

Wilczek M., Bądźmy wierni jego misji, „List do Pani” (czerwiec 2018) nr 6 (265), s. 6. 
Wosicki P., Strata Przyjaciela i Mistrza, „Głos dla Życia” (maj-czerwiec 2018) nr 3 (152), s. 5.

Wosicki P., $W$ temacie obrony życia - bezkompromisowy, „Źródło. Tygodnik Rodzin Katolickich" (20 maja 2018) nr 20 (1377), s. 24.

Zięba A., Bronimy życia w Polsce i świecie, „Głos dla Życia” (czerwiec 2018) nr 3 (152), s. 17-19.

Zięba A., O podziale wśród obrońców życia, „Źródło. Tygodnik Rodzin Katolickich" (8 stycznia 2017) nr 2 (1306), s. 11.

Zięba A., Po 12 latach modlitwy stał się cud, „Miłujcie się” 3 (2018), s. 45-49.

Źródła internetowe

Bochenek M., Cenzura na życie, www.naszdziennik.pl/polska-kraj/192513,cenzura-na-zycie.html (07.02.2018). 